Anna Z. ZMORZANKA

(Lublin, KUL)

\title{
POZYCJA PIOTRA W TEKSTACH GNOSTYCKICH
}

Koptyjskie teksty z Nag Hammadi świadczą o tym, iż gnostycy powoływali się na świadectwo apostołów i uczniów Jezusa, wykorzystując ich autorytet jako bezpośrednich słuchaczy nauki Zbawcy. Jednym z nich jest Piotr, który występuje w siedmiu utworach. Są to: Ewangelia Tomasza, Ewangelia Marii, Apokalipsa Piotra, Dzieje Piotra i Dwunastu Apostołów, List Piotra do Filipa, a także Pistis Sophia (tekst nie należący do zbioru); osoba Piotra jest też wymieniana w Apokryficznym liście Jakuba ${ }^{1}$. Warto się zastanowić, czy gnostycy wyróżnili w szczególny sposób postać, która wg świadectwa Mateusza została przez Jezusa powołana, by kierować Kościołem i czy w ogóle ustosunkowali się do wypowiedzi z Mt 16, 17-18, proklamującej to wydarzenie? Odpowiedź na to pytanie implikuje podstawową kwestię, którą zamierzam przedstawić na wstępie - chodzi mianowicie o gnostyckie rozumienie Kościoła oraz jego struktury.

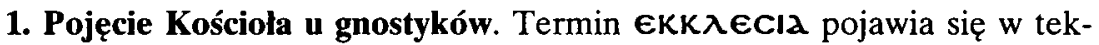
stach gnostyckich $w$ trzech znaczeniach. Pierwsze odnosi się do liturgicznego zebrania - np. w koptyjskim przekładzie Psalmu 34, 18 w Pistis Sophia ${ }^{2}$. Dwa następne (które będą nas tutaj intresowały) oznaczają tzw. Kościół preegzystujący (niebiański, wysoki) i Kościół doczesny (ziemski, niski). Pojęcia te, stanowią podstawę gnostyckiej eklezjologii, którą gnostycy rozwijali w powiązaniu $z$ teodyceą i eschatologią. Idea Kościoła preegzystującego ma swoje korzenie w nauce Walentyna o eonach - emanacjach, wypływających $z$ boskiego Ojca. Walentyn uczył, iż każdy z nich objawia inny aspekt bóstwa, a wszyst-

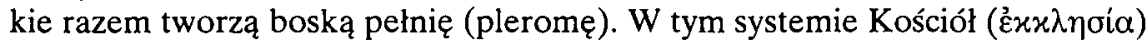
razem $z$ człowiekiem (ởv $\theta \varrho \omega \pi o \varsigma)$ stanowią drugą parę (syzygię) wypływającą z pary: Słowo $\left(\lambda o ́\right.$ o $\varsigma$ ) i Życie ( $\left.\zeta \omega \eta^{\prime}\right)$ : „De Logo autem et Zoe emissum coniu-

${ }^{1}$ Piotr pojawia się też w gnostyckim piśmie Dzieje Piotra, ale ze względu na luźny związek tego utworu z podjętą problematyką został tutaj pominięty. Polski przekład tego utworu z j. koptyjskiego zob. W. Myszor: Dzieje Piotra, STV 15 (1977) z. 2, 169-175.

2 Por. Pistis Sophia I 51, w: Nag Hammadi Studies: The Coptic Gnostic Library 9 (= NHS:CGL), ed. C.S. Schmidt, Leiden 1978, 96. 
gationem Hominem et Ecclesiam"3 . Pojęcie Kościoła preegzystującego wprowadza też autor Traktatu trójdzielnego, który pisze iż „nie tylko Syn istnieje od początku, lecz także sam Kościół jest od początku”4 Kościół ten, jak zauważa dalej autor, skupić miał w sobie „licznych ludzi, którzy istnieli przed eonami, którzy są nazwani we właściwym sensie eonami eonów"5. Podobne przedstawienie Kościoła preegzystującego znajdujemy u walentynianina Teodota, który w powiązaniu $z$ tą ideą wprowadził też pojęcie Kościoła niskiego. Według tego autora Kościół jest ziemskim odpowiednikiem Kościoła preegzystującego powstał on poprzez wylanie przez Chrystusa (Zbawcę) światła gnozy na tych, którzy tutaj na ziemi do niego przynależą:

„Widzialna część Chrystusa była Mądrością i Kościołem pochodzącym z wyższego nasienia, z którego się ona rozwinęła przez pośrednictwo elementu cielesnego"6.

Podobną myśl o ziemskim Kościele gnostyków formułuje autor Traktatu o poczqtku świata; wspomina on o Kościele skupiającym w sobie nasienie światla, który się pojawia pośród tworów zepsucia:

„Uznano, że ma on (w sobie) wszystkie nasienie (światła) dzięki nasieniu mocy, które się [z nimi] było zmieszało"7.

Obie wypowiedzi jednoznacznie charakteryzują członków Kościoła widzialnego. Są nimi ludzie ducha (pneumatycy), którzy pojawili się w świecie (gnostycy, prorocy), określani też, z racji swej kondycji, mianem „obcych”. Charakterystykę Kościoła ziemskiego uzupełnia też inna z wypowiedzi Teodota, który pisze:

„Duch, którego w szczególny sposób posiadał każdy z proroków dla ich posługi, został wylany na wszystkich (należących) do Kościoła"8.

Słowa te świadczą o tym, iż poza prorokami (czyli gnostykami, posiadającymi światło ze swej natury), w Kościele tym byli również ci wszyscy, którzy otrzymali światło (lub mogli otrzymać) za pośrednictwem nauki (słowa). Jeszcze wyraźniej o podziale istniejącym w lonie Kościoła gnostyckiego pisze autor Księgi Tomasza, który wyróżnia dwa rodzaje członków (wiernych), są to

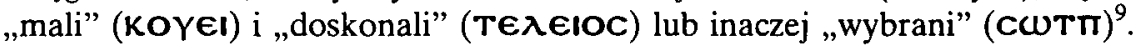

${ }^{3}$ Irenaeus, Adversus haereses I 1, 1, SCh 264, 30.

4 Tractatus tripartitus, NHC I 5:57, 30; NHS:CGL 22, ed. H.W. Attridge, Leiden 1985, 202.

5 Tamże, NHC I 5:158, 30-34; NHS:CGL 22, 205.

${ }^{6}$ Clemens Alexandrinus, Excerpta e Theodoto 26, 1, GCS 17, 94, tłum. P. Siejkowski: Klemens Aleksandryjski, Wypisy z Theodota, ŹMT 22, Kraków 2001, 43.

7 Tractatus de origine mundi (II 5), cytuję za: K. Rudolph, Gnoza: istota i historia późnoantycznej formacji religijnej, tłum. G. Sowiński, Kraków 1995, 182.

8 Clemens Alexandrinus, Excerpta e Theodoto 24, 1, GCS 17, 94, ŹMT 22, 43.

9 Podzial na „małych" i ,doskonałych" odpowiada walentyniańskiemu podzialowi na psychikow i pneumatyków, por. Irenaeus, Adversus haereses I 7, 1-5, SCh 264, 100-112. 
Przy czym zauważa, że każdy, kto przynależy do tzw. „małych”, może stać się doskonały („Tedy ty jesteś mały, zanim staniesz się doskonały”10), przyjmując (tak jak u Teodota) gnozę za pośrednictwem proroków.

Przynależność do grona doskonałych łączyła się ze swoiście pojmowanym prymatem, jaki dawał autorytet gnostyckiego mistrza, przekazującego treść objawienia tajemnego (gnozę) swoim uczniom. Autorzy gnostyccy często przypisywali go uczniom Jezusa, chociaż, jak stwierdza autor Apokryficznego listu Jakuba, nie wszystkim $\mathrm{z}$ dwunastu uczniów została objawiona cała nauka Zbawcy ${ }^{11}$. Wśród wtajemniczonych najczęściej wymieniani są: Tomasz, Jakub, Maria i Piotr. Postać Piotra jako gnostyckiego apostoła szczególnie została wyróżniona w trzech utworach: Apokalipsie Piotra, Dziejach Piotra i Dwunastu Apostołów, Liście Piotra do Filipa, co świadczyć może o istnieniu w łonie gnostycyzmu wpływów judeo-chrześcijańskich ${ }^{12}$. Z kolei utwory należące do tradycji Tomasza i Marii umniejszały jego znaczenie, łącząc go z Kościołem „małych".

2. Piotr jako czlonek Kościoła „Małych”. Pogląd na temat istnienia we wspólnotach gnostyckich dwóch kategori wyznawców - „wybranych” i „,małych" unaoczniają Ewangelia Tomasza i Ewangelia Marii. W Ewangelii Toma$s z a$ kwestia istnienia takiego podziału pomiędzy uczniami jest szczególnie ostro zarysowana, a pojawia się w związku z pytaniem o sukcesję po odejściu Jezusa: „Wiemy, że odejdziesz od nas, kto będzie naszym przełożonym"13. Fragment 34, 30-35, 14, przedstawiający rozstrzygnięcie tego problemu, stanowi paralelę do Mt 16, 15-19. Warunkiem objęcia kierownictwa w grupie jest bowiem właściwe rozpoznanie pochodzenia i natury Jezusa: „Porównajcie i powiedzcie mi, kogo przypominam"14. Próbę taką podejmują kolejno: Piotr, Mateusz i Tomasz. Odpowiedzi, jakich udzielają Piotr i Mateusz porównujący Jezusa do anioła czy sprawiedliwego, nie odbiegają od przyjętych w judaizmie zwyczajów - słuchacze nauk Jezusa w Mt 16,14 porównują go m.in. do Jana Chrzciciela, Jeremiasza, Eliasza. Odmiennie na ich tle prezentuje się odpowiedź Tomasza, który, rozpoznając w Jezusie boskiego wysłannika, rezygnuje z porównań:

„Nauczycielu, moje usta nie ujmują zupełnie tego, abym powiedział do kogo jesteś podobny"15.

\footnotetext{
${ }^{10}$ Liber Thomae, NHC II 7:139, 11; NHS:CGL 21, ed. B. Layton, Leiden 1989, 184.

11 Por. Epistula Jacobi apocrypha, NHC I 2:1, 22-24, thum. W. Myszor - A. Dębska: Teksty z Nag-Hammadi, PSP 20, Warszawa 1979, 109.

12 Por. G.N. Stanton, 5 Ezra and Mathew Christianity in the Second Century, JTS 28 (1977) 70.

13 Evangelium Thomae, NHC II 2:34, 25-26, PSP 10, 209.

14 Tamże, NHC II 2:34, 31-32, PSP 20, 209.

15 Tamże, NHC II 2:35, 3-4, PSP 20, 209.
} 
A zatem, $\mathrm{z}$ trzech uczniów, to właśnie on okazuje się gnostykiem, mającym dar właściwego rozpoznania: „napiłeś się ze źródła kipiącego, które ja odmierzyłem"16 i to jemu zostaje powierzone przyszle kierownictwo grupy. Akt ten przypieczętowuje wtajemniczenie Tomasza (aluzja do Mt 16,17). Nie mogą go przejść pozostali uczniowie, którzy posiadają odmienną naturę - wizja trawiącego ich ognia stanowi aluzję do różnicy natur. Jezus określa rolę, jaką spełniać ma wobec nich wybrany: „Istnieje światłość w człowieku światłości i on oświetla cały świat"17. Uczniowie zaś, aby osiągnąć królestwo, muszą być jak dzieci $^{18}$. W utworze pojawia się wiele zaleceń skierowanych pod adresem wspólnoty „małych”, którzy muszą się poddać kierownictwu wybranego (symbolika dużej ryby i małych ryb - 33, 30-33) i stosować odpowiednie praktyki, przybliżające ich do celu ${ }^{19}$.

Z kolei w Ewangelii Marii bezpośrednim świadkiem gnostyckiego objawienia staje się gnostyczka Maria (Mariham ${ }^{20}$, która przekazuje jego treść pozostałym uczniom: „To, co ukryte przed wami, objaśnię wam”21. W opozycji do niej występuje Piotr ${ }^{22}$, który kwestionuje prawdziwość jej objawienia. Utwór, kończy wystąpienie Lewiego (obrońcy Marii), wzywające pozostałych, by stali się doskonałymi:

„ubierzmy się w człowieka doskonałego, ruszajmy, jak nam polecił, przepowiadajmy ewangelię, nie ustanawiając innego celu ani innego prawa poza tym, co Zbawca powiedział" 23 .

Autorzy obydwu utworów przedstawili Piotra w bliskim gronie uczniów Jezusa, lecz nie włączyli go do grona wybranych. Razem z innymi uczniami, uznającymi przewodnictwo duchowe gnostyków, tworzy on wspólnotę małych, których celem jest duchowe doskonalenie (Ewangelia Tomasza) i przepowiadanie Ewangelii (Ewangelia Marii).

3. Piotr jako świadek misterium. Odmiennie kondycję Piotra przedstawiają trzy kolejne utwory: Apokryficzny list Jakuba, Pistis Sophia oraz Apokalipsa Piotra. Piotr jest w nich bowiem ukazany (podobnie jak w omówionych wcześ-

${ }^{16}$ Tamże, NHC II 2:35, 5-6, PSP 20, 209.

17 Tamże, NHC II 2:38, 7-9, PSP 20, 212.

18 Por. tamze, NHC II 2:36, 35-37, 2, PSP 20, 211

19 Zalecenia te przedstawiają m.in. 31, $25-33,21 ; 33,18-19$ i 37, 25-35.

${ }^{20} \mathrm{Na}$ temat statusu Marii jako gnostyczki zob. W. Myszor, Wstęp, w: Ewangelia Marii, thum. tegoż, STV 13 (1975) nr 2, 150 (dalej cyt.: W. Myszor, EwgM) oraz A. Marjanen, The Woman Jesus Lowed: Mary Magdalene in the Nag Hammadi Literature and Related Documents (NH and Manichaean Studies 40), Leiden 1996, 94-121.

21 Evangelium Mariae, BG 10, 4-6, W. Myszor, EwgM, s. 156.

22 Konflikt pomiędzy Piotrem a Marią zaznacza się też w Ewangelii Tomasza 54, 19-20.

${ }^{23}$ Evangelium Mariae, BG 18, 16-21, W. Myszor, EwgM, s. 159. 
niej utworach - Tomasz i Maria) jako adresat tajemnej nauki Zbawcy, co wyraźnie wzmacnia jego autorytet (jako gnostyka) i przyszlego proroka ${ }^{24}$.

W Apokryficznym liście Jakuba Piotr bezpośrednio nie występuje, ale literacki autor pisma kierowanego do „brata Kerynta" 25 , informuje, iż on i Piotr zostali wprowadzeni w tajemną naukę Zbawcy:

„Ponieważ ty prosiłeś mnie o wysłanie tobie tajemnej nauki, która objawiona została mnie [i] Piotrowi przez Pana"26.

W dalszej części autor przedstawia treść wizji, a na koniec wspomina o złożonym przez niego i Piotra dziękczynieniu ${ }^{27}$. W piśmie wyraźnie podkreślane jest pierwszeństwo Jakuba, co uzasadnia forma literacka oraz przynależność do tradycji.

W Pistis Sophia i w Apokalipsie Piotra autorytet Apostoła zostaje jeszcze wyraźniej podbudowany. W utworach pojawiają się bowiem zapowiedzi dotyczące przyszłej roli Piotra w Kościele, związanej z jego prymatem, na co wskazują wyraźne aluzje do tekstu Mateusza (Mt 16, 16-19).

W Pistis Sophia, którą można zaliczyć do tradycji Marii ${ }^{28}$, Piotr (nazywany MaKaPIOC i TாNa TIKOC) zostaje wprowadzony w tajemnice Pistis Sophii, która odsłania przed nim misterium pleromy, a następnie otrzymuje od Jezusa błogosławieństwo oraz obietnicę kolejnych wtajemniczeń oraz zapowiedź przyszłej władzy (aluzja do Mt 16,19), jaką będzie posiadał nad swoimi współwyznawcami:

„Ty jesteś błogosławiony pomiędzy wszystkimi ludźmi na ziemi, dlatego ja objawię tobie tajemnicę. Zaprawdę, zaprawdę (2 $\mathrm{AMHN}$ ), powiadam ci, ja wypełnię w tobie całą pleromę ( $\pi \lambda \in$ ECUMA), od tajemnicy wewnętrznej, po tajemnicę zewnętrzną. Ja wypełnię ciebie Duchem, gdyż ty jesteś nazwany Pneumatykiem (ர̄NA TIKOC) spełnionym w każdej pleromie. I zaprawdę, zaprawdę powiadam ci, że ty poznasz tajemnice wszystkich miejsc Pierwszej Tajemnicy, tak aby ten, który otrzyma (światło) na ziemi mógł otrzymać światło na wysokości. I temu, komu ty odpuścisz na ziemi, będzie odpuszczone w królestwie Ojca, który jest w Niebie"29.

${ }^{24}$ Zdaniem K. Bergera (Unfehlbare Offenbarung. Petrus in der gnostischen und apokalyptischen Offenbarungsliteratur, w: Kontinuität und Einheit, Freiburg 1998, 261-326) utwory wyróżniajace postac Piotra takie jak Apokalipsa Piotra oraz omawiane w następnym punkcie Dzieje Piotra i Dwunastu Apostotów oraz List Piotra do Filipa świadczyć mogą o istnieniu wśród gnostyków tradycji „Piotrowej”; podaje za: W. Myszor, Apokalipsa Piotra (NHC VII, 3, P. 70, 13-84, 14). Wstęp, przekład z koptyjskiego, komentarz, (cyt. dalej: W. Myszor, ApP), SSHT 31 (1998) 315.

25 Por. Epistula Jacobi apocrypha, NHC I 1, 2, PSP 20, 109. Imię Keryntos zostało zrekonstruowane; chodzi prawdopodobnie o gnostyka Cerynta, por. tamże, s. 125.

26 Tamże, NHC I 1, 8-12, PSP 20, 125.

27 Por. tamże, NHC I 15, 6-9, PSP 20, 123.

${ }^{28}$ Por. Pistis Sophia II 232, 26 - 233, 2. NHS 9, 464-466: „Bowiem Maria Magdalena i Jan i Dziewica będą wywyższeni nad wszystkimi moimi uczniami".

${ }^{29}$ Tamże I 37; NHS:CGL 9, 60. 
Zapowiedź przyszlej władzy w Kościele (jaką Piotr otrzymuje w Pistis Sophia) potwierdzona zostaje w Apokalipsie Piotra. Zbawca w związku z tym wzywa go do doskonałości, bowiem ona jest fundamentem, na którym Kościół ten powstaje ${ }^{30}$, czyni też aluzje do imienia (co wyraźnie wprowadza w kontekst Mt 16,18) oraz w związku z tym ) proklamuje Piotra „początkiem” Kościoła gnostyckiego, analogicznie do proklamacji Piotra „podstawą” Kościoła Powszechnego - w Mt 16, 18 :

„Ty zaś, Piotrze stań się doskonałym razem ze mną ze względu na twe imię, gdyż to ja cię wybrałem. Przez ciebie stworzyłem początek dla pozostałych, których zaprosiłem do wiedzy aby (byli mocni). I ty będziesz mocny, aż (przyjdzie naśladowca sprawiedliwości tego, który cię jako pierwszy powołal"31.

Wydaje się, iż użyte w tym fragmencie pojęcie „początku”, które odnosi się do apostolskiej misji Piotra ${ }^{32}$, może też odnosić się do duchowego prawzoru Kościoła preegzystującego (co nadawałoby temu określeniu sens fundamentalny). $\mathrm{Z}$ misją, jaką otrzymuje Piotr, wiąże się też wizja objawiająca mu przyszłe losy gnostyckiego Kościoła, określonego jako wspólnota „małych”, oraz jego relacji do Kościoła powszechnego; dane jest mu też poznanie ostatecznego triumfu gnostyków:

„Mogą panować nad Małymi, ale potem skończy się (czas) blędu, a odnowi się nie starzejąca się (nigdy) myśl nieśmiertelna" ${ }^{33}$.

4. Piotr jako kierownik Kościoła „Małych” Dwa kolejne utwory to: Dzieje Piotra i Dwunastu Apostotów oraz List Piotra do Filipa. Piotr pokazany jest w nich jako przywódca grupy uczniów. Pierwszy utwór opisuje podróż Piotra i dwunastu apostołów do nieznanego miasta. W piśmie tym pojawiają się określenia pozwalające zidentyfikować gnostycki charakter grupy Piotra, m.in. „obcy”, „obcy wobec świata"34, a za gnostyckim charakterem przekazu przemawiają też nazwy miasta": „Nazwą tego miasta jest 'Siedziba', to jest 'Umocnienie' [...], 'Cierpliwość' i [...]"35, które symbolizują kolejne etapy

${ }^{30}$ Por. Apocalypsis Petri, NHC VII 3:70, 25-27, W. Myszor, ApP, s. 321.

31 Tamże, NHC VII 3:71, 15-28, W. Myszor, ApP, s. 321.

32 Por. W. Myszor, ApP, s. 315-316.

${ }^{33}$ Apocalypsis Petri, NHC VII 3:80, 10-13, W. Myszor, ApP, s. 327, por. Stanton, dz. cyt., s. 7980 i E. Schweizer, The „Matthean” Church, NTS 20 (1974) 216.

${ }^{34}$ Por. Acta Petri et XII Apostolorum, NHC VI 1:24, 3-7, thum. W. Myszor: Dzieje Piotra i Dwunastu Apostolów CNHC VI 1: p. 1, 1 - 12, 22. Wstęp, przeklad z koptyjskiego, komentarz, SSHT 29 (1996) 299 i 301 (dalej cyt.: W. Myszor, ActaP). Gnostycki charakter tego utworu nie jest powszechnie uznawany. Wśród naukowców zdania są podzielone. Za gnostyckim charakterem pisma wypowiadają się: M. Krause, E. Segelberg i P. Perkins, por. C.A. Keller, De la foi a la conneissance: le sens des „Actes de Pierre et des Douze Apotres”, "Revue de Theologie et de Philosophie" 110 (1978) 131-137 i W. Myszor, ActaP, s. 298. 
wędrówki gnostyckiego Kościoła (Siedziba - jako duchowy prawzór, Umocnienie - gnostycki autorytet/gnoza i Cierpliwość - droga do doskonałości). Wątkiem dominującym w opowiadaniu jest spotkanie $z$ Lithargoelem, tajemniczym sprzedawcą peret ${ }^{36}$, w którym ostatecznie Piotr rozpoznaje Chrystusa:

„Odrzekł Lithargoel: «Chcę cię o coś zapytać: kto dał ci to imię Piotr»? Odrzekł mu: «Jezus Chrystus, Syn żyjącego Boga: on to nadał mi to imię». Odpowiedzial i rzekl: «To ja, rozpoznaj mnie Piotrze»"

W scenie rozpoznania centralne miejsce zajmuje wyznanie Piotra: $\overline{\mathrm{IC}} \pi \epsilon \overline{\mathrm{X}} \mathrm{C}$

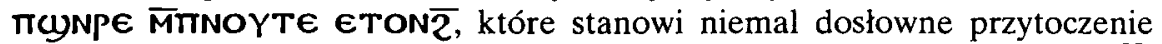

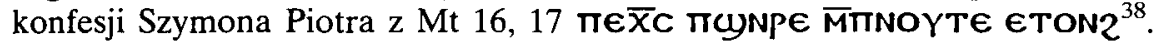
Wyznanie Piotra (w opowiadaniu) zakłada czasowe (przywołuje bowiem wcześniejsze wydarzenia) i logiczne pierwszeństwo wyznania Piotra w Mt 16, 16-18. Można też wskazać na paralelność zdarzeń następujących po wyznaniu Piotra w Mt 16, 16-18 i w Dziejach Piotra. W Ewangelii Mateusza są to: nadanie nowego imienia oraz powołanie Piotra i ustanowienie Kościoła. W Dziejach Piotra jest to ujawnienie tożsamości Lithargoela-Chrystusa i przekazanie gnostyckiego objawienia. W utworze nie ma natomiast bezpośrednich wypowiedzi, które charakteryzowałyby Piotra jako gnostyckiego przewodnika; można jedynie mówić o jego autorytecie i dominacji w grupie: jest on kierownikiem wyprawy i troszczy się o innych.

Autorytet Piotra podkreśla też List Piotra do Filipa, w którym Piotr występuje jako zwierzchnik Filipa, którego upomina i któremu wydaje polecenia. Oficjalny ton listu: „Piotr apostoł Jezusa Chrystusa do Filipa, naszego brata umiłowanego i współapostoła" 39 świadczyć też może o sprawowanym przez Piotra urzędzie, jednak pismo tego nie precyzuje. Ponadto Piotr występuje jako przekaziciel gnozy - naucza i odpowiada na pytania. W piśmie tym brak jednak bezpośrednich odniesień do tekstu Mt 16, 16-19.

Podsumowując podkreślić należy, iż, po pierwsze, u gnostyków istniało silne pojęcie autorytetu gnostyckiego mistrza, które kształtowane było w kontekście eklezjologii. Po drugie, spośród pism gnostyckich odwołujących się do

${ }^{35}$ Por. tamże, NHC VI 1:2, 2-4, W. Myszor, ActaP, s. 299.

${ }^{36} \mathrm{Na}$ temat symboliki perły u gnostyków por. W. Myszor, Sprzedawca peret $w$ „Dziejach Piotra i Dwunastu Apostotów" z VI kodeksu z Nag Hammadi, VoxP 7 (1987) z. 12-13, 303-305.

37 Acta Petri et XII Apostolorum, NHC VI 1: 9, 8-15; W. Myszor, ActaP, SSHT 29 (1996) 301.

38 Cytuję za: J. Sell, Simon Peter's „Confession” and the Acts of Peter and the Twelve Apostles, „Novum Testamentum” 21 (1979) 349.

39 Epistula Petri ad Philippum, NHC III 2, List Piotra do Filipa (Epistula Petriad Philippum, Nag Hammadi Codex VIII 2), VoxP 17 (1997) z. 32-33, 421. 
autorytetu apostołów wyodrębnić można grupę utworów należących do tzw. tradycji Piotra, uznającej w Piotrze gnostyka i nauczyciela gnozy. Należą do nich: Apokalipsa Piotra, Dzieje Piotra i Dwunastu Apostotów oraz List Piotra do Filipa; do tej grupy zaliczyć też można Pistis Sophia. Wszystkie one, poza Listem Piotra do Filipa, nawiązują też do Mt 16, 16-19, wspominając takie wydarzenia jak: rozpoznanie Jezusa przez Piotra (Mt 16, 16 - Dzieje Piotra i Dwunastu Apostolów), nadanie apostołowi imienia (Mt 16,18 - Dzieje Piotra, Apokalipsa Piotra), ustanowienie prymatu i powołanie Kościoła (Mt 16, 18 Apokalipsa Piotra) oraz powierzenie Piotrowi kluczy (Mt 16, 19 - Pistis Sophia). W nawiązaniu do tych wydarzeń Piotr ukazany zostaje jako „początek” gnostyckiego Kościoła.

\section{LA POSITION DE PIERRE DANS LES TEXTES GNOSTIQUES}

\section{(Résumé)}

Dans le présent article l'auteure fait l'analyse de sept ouvrages dans lesquels apparaît le personnage de Pierre. Ces ouvrages peuvent être répartis en trois groupes. Dans le premier groupe (l'Évangile selon Thomas, l'Évangile selon Marie) Pierre est présenté en tant qu'auditeur de l'enseignement de Jésus/Sauveur. Dans le deuxième (La lettre apocalyptique de Jacques, l'Apocalypse selon Pierre, Pistis Sophia) il est présenté en tant que témoin du mystère. Dans le troisième (Les actes de Pierre et des douze apôtres, La lettre de Pierre à Philippe) en tant que dirigeant d'une communauté (gnostique). Dans la conclusion, on fait observer qu'il existait chez les gnostiques un courant faisant appel à l'autorité de Pierre comme membre de l'Église des Parfaits/Choisis et en tant que témoin de la révélation secrète du Sauveur. Ce courant se référait aussi à la tradition de Matthieu. 